\title{
DISTRIBUTION, STATUS AND NATURAL HISTORY NOTES ON ROCKHOPPER PENGUINS (EUDYPTES CHRYSOCOME) IN CHILE
}

\author{
DISTRIBUCIÓN, ESTATUS Y NOTAS SOBRE LA HISTORIA NATURAL DEL PINGÜINO PENACHO \\ AMARILLO (EUDYPTES C.CHRYSOCOME) EN CHILE
}

\author{
Manuel Marin ${ }^{1,2}$ D. Oehler ${ }^{1}$ \& Alejandro Kusch ${ }^{1,3}$
}

The Rockhopper Penguin (Eudyptes chrysocome) has a circumpolar distribution and is the most widespread of the crested penguins (Williams 1995). In Chile the non breeding distribution still basically unknown and its breeding distribution is patchily known, with a majority of census data being provided by the efforts of Claudio Venegas and later surveys conducted by Gerry S. Clark, conducted in the late 1970's and 1980's (Venegas, 1978, Venegas \& Jory, 1979, Clark, 1988, Clark et al., 1984, Clark et al., 1992, Venegas, 1999). Surveys made by Clark and company discovered several new colonies and provided colony size estimations of new and known colonies that they visited. Clark's surveys, provided a base line data for population estimations generated by additional investigators, including: Woehler (1993) and Bingham \& Mejias (1999). However, further studies are required to determine the total population of this taxon, along the coast of Chile. Here we present a synthesis of current knowledge plus additional information gathered during our surveys through the Chilean fiords, from 2003 through 2010.
For the breeding distribution we surveyed the Chilean fiords from Puerto Montt to Diego Ramirez Archipelago and divided the fiords on two sections: the northern, from Golfo de Penas south to the Strait of Magellan and the southern, going from the Strait of Magellan south to the Archipelago Diego Ramirez. We reviewed the literature and complemented these data with our own observations on the breeding colonies of the Rockhopper Penguin (Eudyptes $c$. chrysocome) along the Chilean fiords from north to south. We conducted six expeditions aboard the MV Chonos along the southern section and one trip to Isla Noir aboard the MV Cabo Tamar. Additional trips between 2002-2006 (MM) conducted 24 crossings between Puerto Montt and Cape Horn and between 2006-2008, 8 crossings between Puerto Natales and Cape Horn on board MS Nordnorge, MS Nordkapp, and MS Fram, and between 2001-2003, 13 trips from Punta Arenas to Puerto Williams and back to Punta Arenas on board of MV Terra Australis, and MV Mare Australis. During October 2002 (AK) did one trip from Punta Arenas to Cape Horn on board

\footnotetext{
${ }^{1}$ Feather Link, Inc. 1013 Westchester way, Cincinnati, OH 45244, USA.

${ }^{1}$ Angeles County Natural History Museum, Section of Ornithology, 900 Exposition Boulevard, Los

Angeles CA 90007, USA. Dirección actual: Casilla 15, Melipilla, Chile. mma95@hotmail.com

${ }^{1}$ Casilla 19, Punta Arenas, Chile. alekusch@yahoo.com
} 
of LAM Austral II, two trips in November 2000 on board of $R / R$ Pto. Eden between Pto. Natales and Pto. Montt, One trip in October 2007 on MV Chonos Punta Arenas to Cabo Pilar, and Pto. Natales to Canal Concepcion in December 2006 and January 2007, aboard MV Yepayek and one trip on November 2010 between Pto. Natales and Punta Arenas on board MV Cabo Tamar.

Portable GPS units (Garmin GPS 38, GPS 45XL, and Etrex) were utilized to determine geographical positions where possible, otherwise latitude and longitude

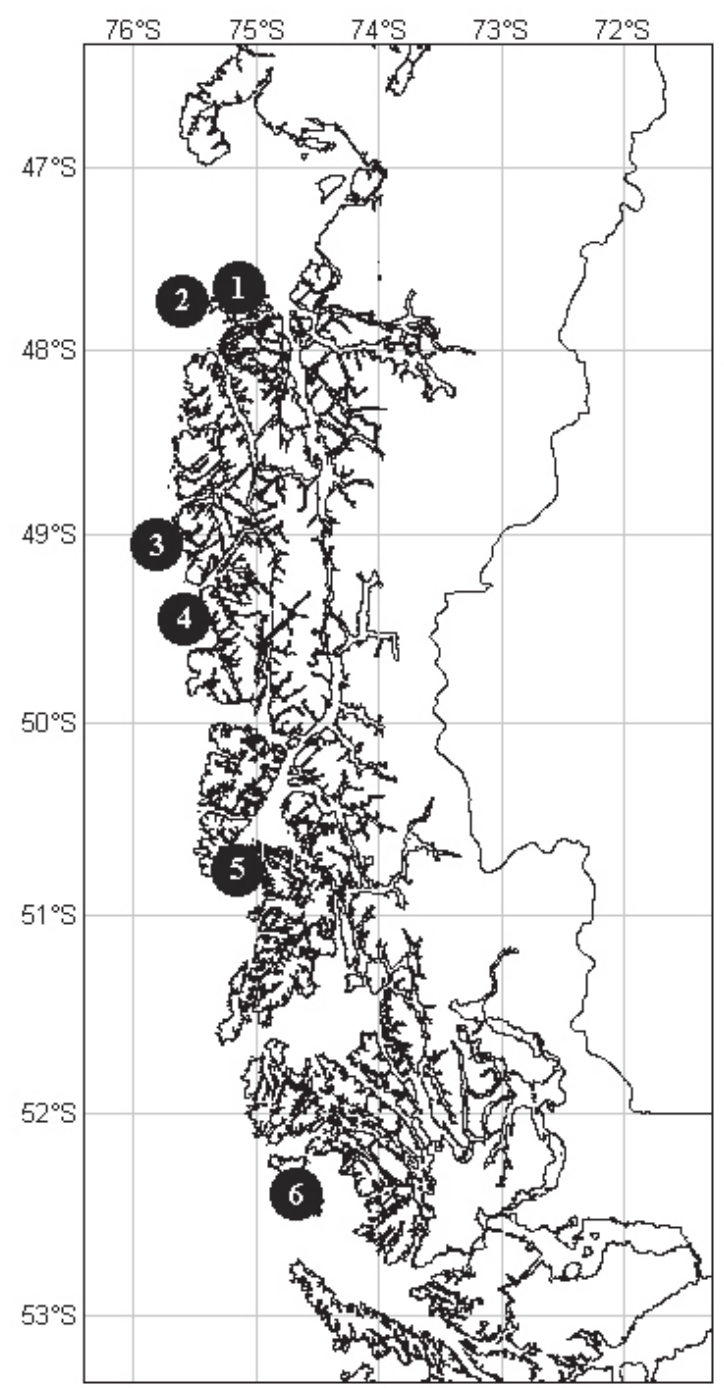

Fig. 1. - Colonies of Rockhopper Penguins between Golfo de Penas and the Strait of Magellan, northern zone. (see also Table 1). positions were determined from navigational charts or taken from Riso Patron (1924) or Paynter (1988). The nomenclature of eggs shapes follows those given by in Palmer (1962). Eggs measurements were taken with a dial caliper to the nearest $0.1 \mathrm{~mm}$ and the eggs mass were taken with AVINET pesolas of 100 and $300 \mathrm{~g}$. The eggs were either fresh or slightly incubated eggs.

\section{Breeding Distribution}

From north to south Golfo de Penas to Diego Ramirez islands, along the Chilean fiords we found that all colonies were located on the seaward side and mainly in the outer islands or heavily exposed islands of the Chilean fiords. No colonies were observed on islands on the inner channels, where birds were rarely observed at sea. Although we do have some observations of birds on the inner channels, these consisted of small rafts of what appeared to be foraging individuals. If any colony were located at a channel entrance, such as the one on Isla Buenaventura, the colonies were exposed to the open seas.

Our main survey routes on the northern section were through the internal channels with little outer islands explorations, thus we relied mainly on published accounts and some unpublished information from local fisherman and travelers through the area. The northern most breeding colonies seem to be to be located on the northern tip of the Archipelago Guayaneco at the southern end of the Golfo de Penas (see also Table 1). Isla Rugged a small islet containing a small colony, two independent and unpublished reports one by $\mathrm{R}$. Mattus and the second by local fishermen (pers. comm.) of 30 and 60 individuals respectively. Clark et al., (1984) and Clark (1988) reported a small colony slightly west and south of Rugged on Islote Solitario, there are contradicting reports on the same spot by the same author, Clark et al., (1984) reported that on the island were observed 37 adults and 6 nestlings in January and Clark (1988) reports 11 adults and six nestlings. Bingham \& Mejias (1999) reported 200 breeding pairs for the same site, and their number came from an unknown source. Considerable, further south Venegas (1978) reported an unconfirmed colony on an island of the Notables Group on Bahia Dineley with an unknown number of breeding birds, and a small colony of 3-4 pairs on an island of the Vorposten Group on Golfo Ladrillero. Bingham \& Mejias (1999) reported 500 pairs for the Bahia Dineley site and 300 
Table 1.- Known breeding sites of Rockhopper Penguins in Chile.

A) NorTHERN SECTION

\begin{tabular}{llcll}
\hline Site \# & Site & Breed. pairs & \multicolumn{1}{l}{ Position } & Main source \\
\hline 1 & Isla Rugged & 30 & $4739 / 7509$ & Fisherman \& R. Mattus Pers comm. \\
2 & Isla Solitario & 35 & $4742 / 7542$ & Clark et al. 1984 \\
3 & G. Notables & $?(500)$ & $4854 / 7554$ & $\begin{array}{l}\text { Venegas, 1999; Bingham \& Mejias, } \\
1999\end{array}$ \\
4 & G. Vorsposten & $?(300)$ & $4922 / 7542$ & Venegas, 1999; Bingham \& Mejias, \\
5 & I. Buenaventura & 500 & $5045 / 7509$ & Clark et al. 1984 \\
6 & I. Reina Adelaida & 400 & $5226 / 7440$ & Bingham \& Mejias, 1999 \\
& Sec A Total & 1,765 & & \\
\hline
\end{tabular}

B) SOUTHERN SECTION

\begin{tabular}{llcll}
\hline Site \# & Site & Breed. pairs & Position & Main source \\
\hline 7 & Isla Desolacion & 3,000 & $5245 / 7444$ & Venegas 1999 \\
8 & Isla Recalada & 0 & $5320 / 7410$ & Oehler et al., 2007 \\
9 & Isla Noir & 158,200 & $5430 / 7300$ & Oehler et al., 2008 \\
10 & Isla Terhalten & 3,000 & $5527 / 6704$ & Present work \\
11 & Isla Carolina & ?? & $5527 / 6930$ & Murphy, 1936 \\
12 & Isla Sesambre & 90 & $5528 / 6701$ & Present work \\
13 & Isla Ildefonso & 86,400 & $5543 / 6920$ & Kirkwood et al., 2007 \\
14 & Isla Barnevelt & 10,800 & $5549 / 6647$ & Clark et al., 1992 \\
15 & Isla Hall & 500 & $5553 / 6725$ & Clark et al., 1992 \\
16 & Isla Hornos & 600 & $5557 / 6717$ & Clark et al., 1992 \\
17 & Diego Ramirez & 132,721 & $5631 / 6843$ & Kirkwood et al., 2007 \\
& Sec B Total & 395,311 & & \\
& TOTAL & 397,076 & & \\
\hline & & & & \\
\hline
\end{tabular}

pairs for the Ladrillero site. About 1,000 birds on Isla Buenaventura in Canal Concepción were reported by Clark et al., (1984) and the southernmost colony of the northern section of about 800 birds, was located on Archipelago Reina Adelaida, Bingham \& Mejias (1999). The northern section is the least explored area and the real population status of several colonies is uncertain. Most likely there are several undiscovered colonies and larger number of individuals of what we report here, but unfortunately the sites are of very difficult access. Furthermore a new threat is arriving to the general area which is the salmon farming. 


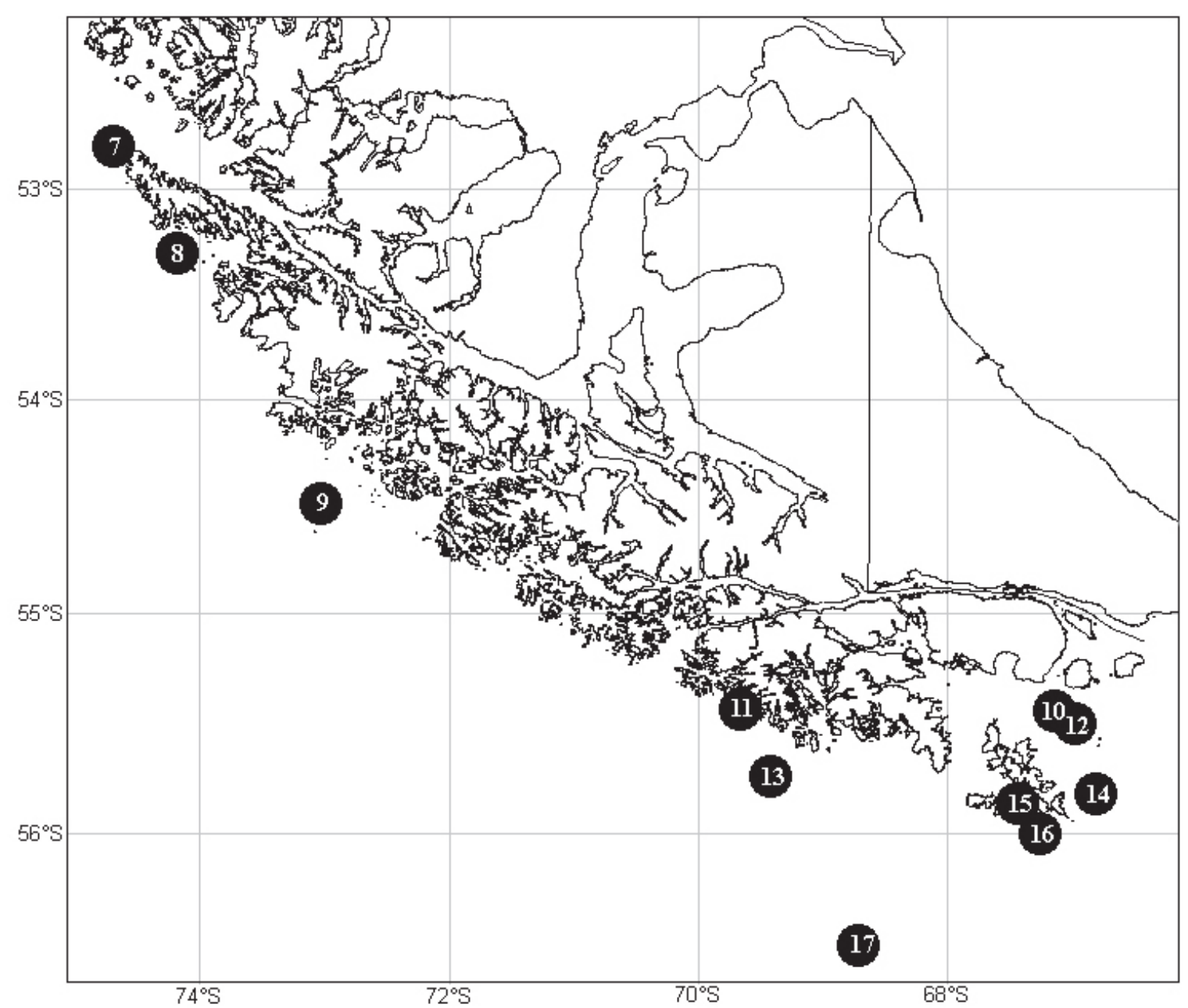

Fig. 2.- Colonies of Rockhopper Penguins between the Strait of Magellan and the Diego Ramirez Archipelago, the southern zone (see also Table 1).

We conducted several surveys through the inner and outer areas of the southern Chilean fiords (see above) and we complemented our observations with what we found on the literature, which is by far better known than the northern section. The northernmost colonies were reported by Venegas (1978) and Venegas \& Jory (1979) in Cabo Pilar on the northwestern most part of Isla Desolación, two colonies of about approximately 2,000 to 3,000 birds each. Further south along the outer islands, the next reported colony was on Isla Recalada (Venegas, 1978). However, we found that the colonies at Recalada Island were extirpated earlier than 2005 which was the time of our visit (Oehler et al., 2007). As we move farther south the next colony in line is on Isla Noir. Several researcher and travelers have described the penguins on Noir, perhaps one of the earliest report was from De Agostini, whom visited the island in November 1929 (De Agostini, 2005). Venegas (1978, 1998) and Clark (1988) all reported birds nesting on Noir; Venegas estimated a population of 70,000 pairs, although he was not able to survey the entire island, due to weather conditions incurred. Bingham \& Mejias (1999) mentioned the same estimation number as Venegas (1998). We visited Isla Noir on five occasions and estimated (Oehler et al, 2008) a population of $158,200(139,716$ - 176,700) breeding pairs, a considerable larger number than previous estimated. The next colony to the south 
would be in Caroline Island, a colony of unknown size where R. Beck encountered birds brooding young in December (Murphy, 1936). We surveyed Caroline and nearby islands in November 2008 and we could not find the colony referenced by Beck in Murphy (1936). On the same latitude, but to the east in the Nassau Bay, is Terhalten Island where birds were first reported nesting by Clark (1988) in January 1985, with additional sightings of penguins on the island reported by Wallace (1991). Later Clark et al. (1992) gave an estimation of 3,000 pairs on the northern and southwest coast. We conducted yacht-based surveys of Terhalten on 22 December 2005, 4 February 2006 and 29 November 2006, and landed-based surveys on 17, 18 December 2007 and 6,7 and 8 of November 2008 and estimated the population as ca. 3,000 pairs. We previously reported Oehler et al., (2008) an estimated 1,000 breeding pairs, based on the yachtbased count in 2005/6 and an incomplete count on a visit on 2007. Adjacent to Terhalten to the SE is Sesambre Island, where we conducted a land-based surveyed on 7 November 2008 and directly counted 90 (86-94) breeding pairs. The colony on Sesambre is a newly undescribe colony and Clark (1988) reported no birds on this island in 1985, indicating that might be a recent colony. Further south and to the west are the several colonies at Ildefonso Islands on which Kirkwood et al., (2007) estimated a population of about 86,400 breeding pairs and Clark et al., (1992) estimated about 100,000 pairs. For isla Barnevelt, Clark et al., (1992) reported 10,800 breeding pairs from at least 3 different sites around the island. However, Bingham \& Mejias (1999) reported 7,000 breeding pairs (from one or more sites?). Clark et al., (1992) reported 500 pairs at isla Hall and 600 pairs on isla Hornos, just behind Catedral Rocks. The population of the southernmost sites, at the Diego Ramirez archipelago, have been estimated by several authors although the most recent is Kirkwood et al., (2007) with a population estimated in 132,721 breeding pairs.

Published data and our own observations on the 17 breeding sites mention here (see Table 1 \& Figs.1,2) along the coast of Chile including locations such as Noir, Ildefonso and Diego Ramirez that contain multiple colonies, provide us with data that suggest a total of 397,076 breeding pairs of Rockhopper Penguins within Chile. Within the last 50 years or so, this number by far exceeds earlier and previous population estimations for Chile (Table 2). For example
Table 2. Population estimates of breeding pairs of Rockhoppers (Eudyptes chrysolophus) for Chile.

\begin{tabular}{lc}
\hline Autor & Estimated population \\
\hline Johnson, 1965 & small numbers \\
Wilson, 1983 & 75.000 \\
Schlatter, 1984 & 75.000 \\
Woehler, 1993 & 175.000 \\
Bingham \& Mejias, 1999 & 164.800 \\
Kirkwood et al., 2007 & 375.000 \\
Present estimate 2011 & 397.076 \\
\hline
\end{tabular}

Johnson (1965) indicated that in Chile it was "only found in small numbers" and "breeding in Admiralty sound and Brecknock peninsula" both the numbers and sites were far from reality. However, the current high number may be due to several factors such as more surveys and, use of complete inventories through direct observation of individual colonies, in contrast to broad estimates and, colony expansion, such as those observed on Isla Noir and the recent documented colony on the Sesambre Island.

General Distribution

The breeding distribution of Southern Rockhopper Penguins within Chile has been documented to occur from the Diego Ramirez Archipelago $\left(56^{\circ} \mathrm{S}\right)$ at the southern end of South America to about $47^{\circ}-48^{\circ} \mathrm{S}$ around Archipelago Guayaneco at the southern end of the Golfo de Penas. Relatively small number of penguins may come ashore to breed slightly north e.g., around Adventure, Darwin and Anna Pink Bays. However, post breeding distribution remains undetermined and it may be possible that a number of birds follow a pelagic northerly movement along the Humboldt Current, particularly birds from the northern most colonies. This hypothesis is supported by a number of coastal and near shore records along the Chilean coast north of Golfo the Penas. The northernmost record is of 3 birds found at Punta Talca, prov. Limari (30 58' S) (Tabilo et al. 1996); Philippi (1964) mentions one bird on Cachagua Island, prov. Petorca (32 $35^{\prime} \mathrm{S}$ ); Brito (2007) reported on a single individual found on

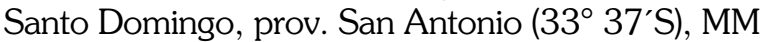
(Umpubl.) found a raft of 4 birds at sea just south and west of Mocha island, prov. Arauco ( $\left.36^{\circ} 22^{\prime} \mathrm{S}\right)$ and 


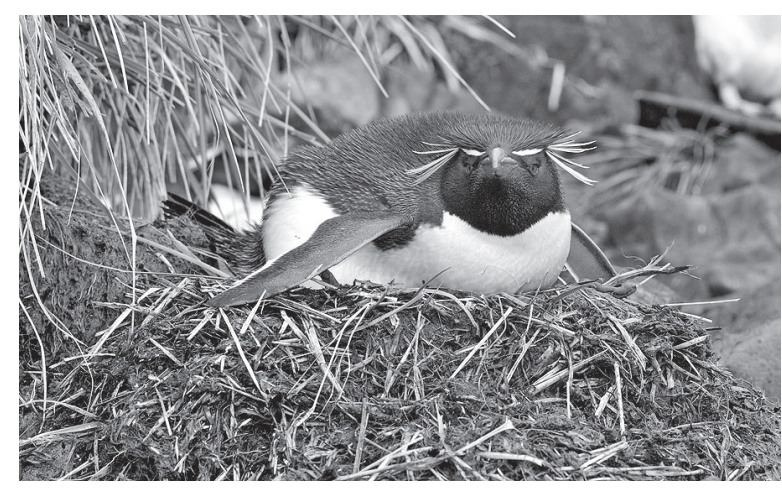

Fig. 3.-Rockhopper Penguin sitting on the nest.

Corti (1997) reports a single bird on the Corral Bay, prov. Valdivia $\left(39^{\circ} 48^{\prime} \mathrm{S}\right)$. These records indicate a northerly movement through the Pacific of at least part of the population.

\section{Breeding and Seasonality}

Most of the nests were small depressions on the ground, lined with grasses where the eggs were laid. Sometimes nests where elevated with some mud, mixed with dry grass and on top was a concave depression where the eggs rested. Some nests were build over the Tussock grass and the concave depression were lined with grasses, and others were lined with dry parts of shrubs (Hebe elliptica) (Fig.3 \& 4). The average diameter of the nest depression was $182.3 \mathrm{~mm}$ ( $\mathrm{DE}=14.06$; Range $160-210 \mathrm{~mm} ; \mathrm{N}=$ 30). The eggs were pale greenish blue as base color with a superficial chalky layer white in color and non glossy. These became soiled with brown mud over time and it appeared that the more soiled eggs were those that had been incubated for a longer period, which might be a factor in determining the general stage of incubation. The clutch size were typically two eggs, although nests with one or three eggs were not uncommon and occasionally four eggs were found (Fig. 4). We attribute the clutch size of one to depredation (see below). The nests with 3 or 4 eggs appear to be the result of some females/pairs procuring nests of bordering pairs and depositing their eggs on the adjacent nest, a situation that was observed on at least in four occasions. Although we previously provided egg measurements (Kusch et al., 2007), here we provide

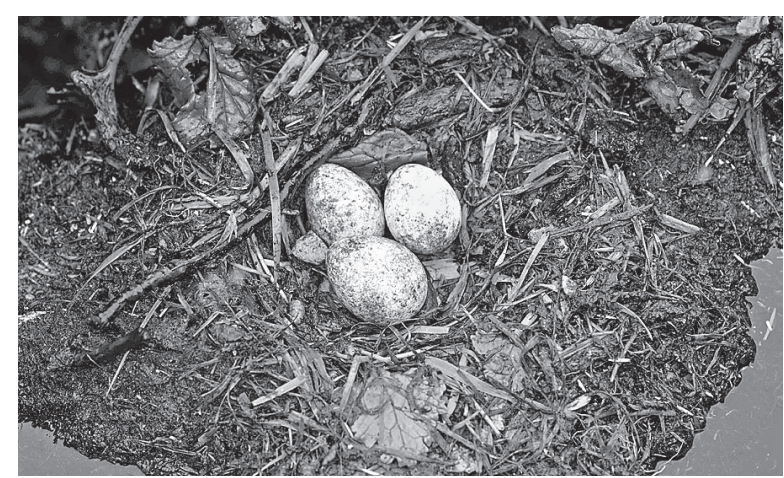

Fig. 4.- Nest of Rockhopper Penguin with tree eggs (Picture taken in Terhalten island, Bahia Nassau).

additionally egg mass and data representing a larger sample size (Table 3). Egg shapes were: subelliptical $52.4 \%$, oval $26.2 \%$, short subelliptical $13.6 \%$, long subelliptical $4.8 \%$, and short oval $2.9 \%(\mathrm{~N}=103)$. We found a considerable difference on egg mass and size among and between the nests, the largest egg mass was more than double the smallest (see also Table 3 and the egg size difference on Fig. 4). Eggs started being laid in late October to early November with chicks hatching by early to mid December. Nestling departed the nests between January and February, although we found birds until mid to late March at the colonies. From early February to mid March we found adults molting before departure. The timing of reproduction and other events coincided closely of that proposed by Venegas (1999).

\section{Mortality}

We observed two main predators involving Rockhoppers Penguins and those were land /air based predators, the Striated Caracara (Phalcoboenus australis) and the Chilean skua (Stercorarius chilensis). Striated Caracara which were constantly present at a majority of colonies and were observed harassing the breeding birds (see also Marin et al., 2006). The caracaras were capable of stealing eggs and nestlings of all ages. Chilean skuas were observed less frequently in several colonies as they foraged for eggs or young (Fig. $5 \mathrm{a}, \mathrm{b})$. On several occasions we observed aggression between skuas and caracara, resulting in the departure of the caracara from the colony site. Crested caracara (Caracara plancus), Chimango Caracara (Milvago 

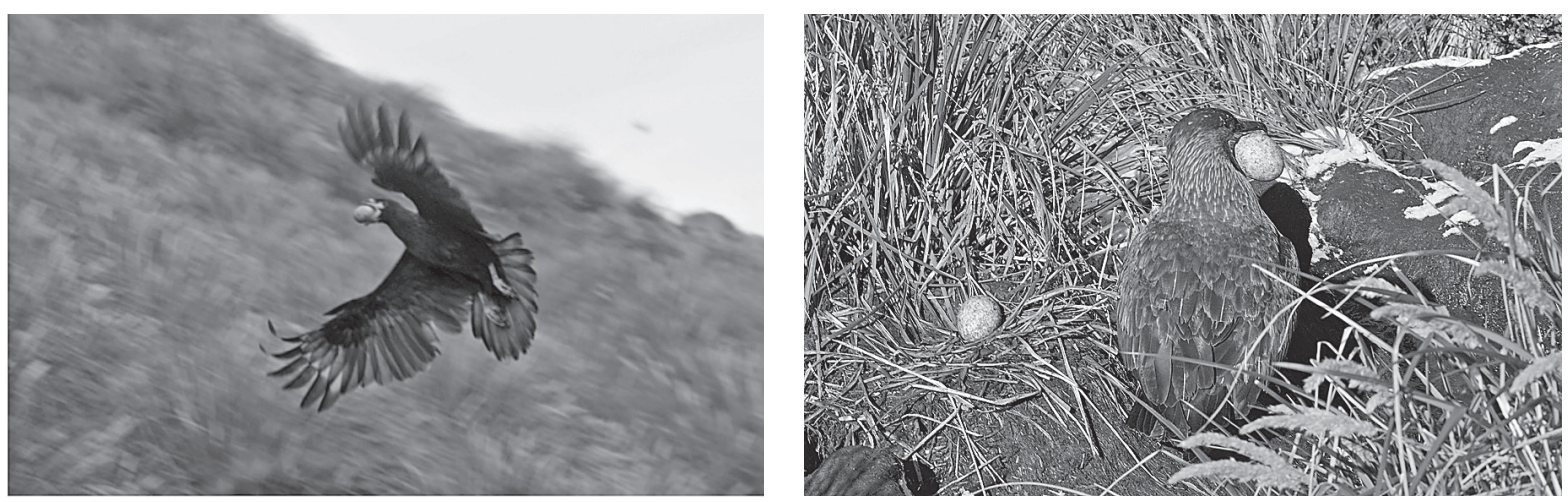

Fig. 5.- Two of the main predators of eggs and nestlings of Rockhopper Penguins in Chile (Left side): Striated Caracara Phalcoboenus australis and (Right side) Chilean Skua Stercorarius chilensis

chimango), Kelp Gulls (Larus dominicanus) and Dolphin Gulls (Larus scoresbii), were also present on some colonies, although it appeared that they were not fully depending on Rockhoppers Penguins as their main food supply. Other birds such as the Plumbeous Rail (Pardirallus sanguinolentus) and Blackish Cinclodes (Cinclodes australis) were also observed around the nests, and each species in two occasions were observed pecking eggs. Other predators includes the Southern Giant Petrels (Macronectes giganteus), which were observed on 4 February 2006 on Terhalten island where some individuals were eating a juvenile penguin near the shoreline. On 17 November 2010, a group of approximately 20 giant petrels were observed along the shoreline on Isla Noir. One giant petrel captured an adult Rockhopper Penguin as it came ashore and the group consumed the penguin in less than 10 minutes. A surprising predator was observed on 18 November 2010, a Sea Otter (Lontra felina) actively hunting Rockhoppers as they were arriving to the colony. We observed two attempts by the otter to capture penguins, although both efforts were unsuccessful and resulted

Table 3. Size and mass of Rockhopper (Eudyptes chrysocome) from southern Chile. $(\mathrm{N}=103)$.

\begin{tabular}{lcccc}
\hline Feature & Mean & SD & SE & Range \\
\hline Length $(\mathrm{mm})$ & 66.50 & 3.92 & 0.387 & $50.7-74.8$ \\
width $(\mathrm{mm})$ & 50.33 & 3.32 & 0.328 & $40.1-56.9$ \\
Mass $^{\text {a }}(\mathrm{g})$ & 90.08 & 16.23 & 2.295 & $59-122$ \\
\hline
\end{tabular}

a For mass sample number was $n=50$. only in the injury of one penguin. Other causes of mortality which might be significant, was egg rolling, due to the constant quarrels of other birds attempting to defend nest sites.

\section{ACKNOWLEDGMENTS}

This work was supported by Feather Link, Inc. By grants-in-aid for scientific research from local and international foundations. We thanks Brian and Holly Hunt of African Safari Wildlife Park, Indianapolis Chapter of the American Association of Zoo Keeperss, Faunia, Cincinnati Zoo \& Botanical Garden, and the wave Foundation of the Newport Aquarium for financial support of the expeditions involved. Our gratitude must also be expressed to $\mathrm{W}$. Roger Fry and Leonard Weakly, Jr. for their continued support and participation in this project. We also are grateful to all the people that helped with field work Roger Fry, Rodrigo Gonzalez, Alberto Gutierrez, Kimberly Lenhardt, Joanne Rapley, Susan Schmid, and Leonard Weakly. We also are grateful to Fantastico Sur Birding, to the crews of the M/N Terra Australis, M/V Mare Australis, M/S Nordnorge, M/S Fram, M/S Nordkapp, L.A.M. Austral II, M/V Chonos, and MV Cabo Tamar for transport to different parts of the austral seas. We are also grateful to the reviewers for comments and improving the manuscript.

\section{LITERATURE CITED}

Bingham, M., \& Mejias, E. (1999). Penguins of the Magellan region. Scientia Marina, 63 
(Supplement 1), 485-493.

Brito, J.L. (2007). Curioso registro de Pingüino de Penacho Amarillo en Santo Domingo. Chiricoca, 3, 33-34.

Clark, G. S. (1988). The Totorore voyage. New Zealand: Homelands Pub. Kerikeri.

Clark, G. S., Goodwin, A. J., \& Von Meyer, A. P. (1984). Extension of the known range of some seabirds on the coast of southern Chile. Notornis, 31, 320-334.

Clark, G.S., Cowan, A., Harrison, P. \& Bourne, W. P. (1992). Notes on the seabirds of the Cape Horn Islands. Notornis, 39, 133-144.

Corti, P. (1997). Observación de un Pingüino de Penacho Amarillo Eudyptes chrysocome Foster 1781, fuera de su rango de distribución. Boletín Chileno de Ornitología, 4, 36-37.

De Agostini, A. M. (2005). Treinta años en Tierra del Fuego. Buenos Aires, Argentina: Edición El Elefante Blanco [edición original 1956].

Johnson, A. W. (1965). The birds of Chile and adjacent regions of Argentina, Bolivia and Peru. Vol. 1. Buenos Aires: Platt Establecimientos Gráficos S.A.

Kirkwood, R., Lawton, K., Moreno, C., Valencia, J., Schlatter, R. \& Robertson, G. (2007). Estimates of Southern Rockhopper and Macaroni penguin numbers at the Ildefonso and Diego Ramirez Archipelagos, Chile, Using quadrat and distance-sampling techniques. Colonial Waterbirds, 30, 259-267.

Kusch, A., Marin, M., Oehler, D., \& Drieschman, S. (2007). Notas sobre la avifauna de Isla Noir (54 28' S - 73 00' W). Anales Instituto Patagonia, 35, 61-66.

Marin, M., Kusch, A., Oehler, D. \& Driechman, S. (2006). Distribution, breeding and status of the Striated Caracara Phalcoboenus australis (Gmelin, 1788) in southern Chile. Anales Instituto Patagonia, 34, 65-74.

Murphy, R.C. (1936). Oceanic birds of South America. vol. 1., New York, U.S.A: American Museum of Natural History.

Oehler, D. A., Fry, W. R., Weakley, L. A., \& Marin, M. (2007). Rockhopper and Macaroni Penguin colonies absent from Isla Recalada, Chile. Wilson Journal of Ornithology, 119, 502506.

Oehler, D. A., Pelikan, S., Fry, W. R., Weakley, L.
A., Kusch, A., \& Marin, M. (2008). Status of crested penguin (Eudyptes spp.) Populations on three islands in southern Chile. Wilson Journal of Ornithology, 120, 575-581.

Palmer, R. S. (1962). Handbook of North American Birds. Vol. 1. Yale Univ. Press.

Paynter, R. A. (1988). Ornithological gazetter of Chile. Massachusetts, Cambridge: Museum of Comparative Zoology.

Philippi, R. A. (1964). Catálogo de las aves de Chile con su distribución geográfica. Investigaciones Zoológicas Chilenas, 11, 1-179.

Riso Patron, L. (1924). Diccionario geográfico de Chile. Chile, Santiago: Imprenta Universitaria.

Schlatter, R. P. (1984). The status and conservation of seabirds in Chile. In J.P. Croxall, P.G.H. Evans \& R. W. Schreiber (Eds.) Status and conservation of the world's seabirds(pp. 261269). Cambridge: ICBP Technical Publication No 2.

Tabilo, E., Jorge, R. \& Campusano, J. (1996). Nuevas observaciones sobre la avifauna de Atacama y Coquimbo. Boletín Chileno de Ornitología, 3, 34-36.

Venegas, C. (1978). Pingüinos de Barbijo (Pygoscelis antárctica) y Macaroni (Eudyptes chrysolophus) en Magallanes. Anales Instituto Patagonia. 9, 179-183.

Venegas, C. (1999). Estado de conservación de las especies de pingüinos en la región de Magallanes, Chile. Estudios Oceanologicos, $18,45-56$.

Venegas, C. \& Jory, J. (1979). Guía de campo para las aves de Magallanes. Punta Arenas, Magallanes, Chile: Publicaciones Instituto de la Patagonia, serie Monografías No. 11.

Wallace, G. E. (1991). Noteworthy bird records from southernmost Chile. Condor, 93, 175-176.

Williams, T. D. (1995). The penguins-Spheniscidae. New York: Oxford Univ. Press.

Wilson, G. J. (1983). Distribution and abundance of Antarctic and sub-Antarctic penguins: A synthesis of current knowledge. Cambridge, England: Biomass Scientific Series No. 4, SCAR and SCOR.

Woehler, E. J. (1993). The distribution and abundance of Antarctic and subantarctic penguins. Cambridge, England: Scientific Committee on Antarctic Research. (SCAR). 